\title{
ANALISIS BOOK TAX DIFFERENCES TERHADAP PERSISTENSI LABA, AKRUAL DAN ALIRAN KAS PADA PERUSAHAAN JASA TELEKOMUNIKASI
}

\author{
Buntoro Heri Prasetyo \\ Dosen Tetap Fakultas Ekonomi Universitas Pakuan \\ Lecturer of Economic Faculty at Pakuan University \\ Rafitaningsih \\ Mahasiswa Fakultas Ekonomi Universitas Pakuan \\ Student of Economic Faculty at Pakuan University
}

\begin{abstract}
ABSTRAK
Salah satu topik yang tengah berkembang di bidang akuntansi perpajakan yang menarik perhatian ialah mengenai book tax differences. Hal ini disebabkan karena perbedaan dasar penyusunan dalam penghitungan laba antara komersial dengan perpajakan maka menimbulkan perbedaan besaran jumlah atas penghasilan sebelum pajak (laba akuntansi) dan penghasilan kena pajak (laba fiskal) atau disebut dengan istilah book tax differences. Penelitian ini menggunakan metode analisis regresi. Dari hasil penelitian dapat ditarik kesimpulan bahwa variabel book tax differences yang diproksikan oleh perbedaan permanen dan perbedaan temporer tidak berpengaruh secara signifikan terhadap persistensi laba. Kemudian, perbedaan komersial dan laba kena pajak yang signifikan berperan dalam mengefisiensikan pembayaran pajak.
\end{abstract}

Kata kunci: book tax differences dan persistensi laba.

\begin{abstract}
One topic that was developing in the field of tax accounting which interesting is the book tax differences. This is due to basic differences in the calculation of earnings between the preparation of commercial quantities of tax will cause a number of differences on income before tax (accounting profit) and the taxable income (taxable income) or called the book tax differences. This study used regression analysis. From the research results can be concluded that the variables book tax differences were comparison by the difference in the permanent and temporary differences not significantly affect earnings persistence. Then, the difference in the commercial and taxable income a significant role in streamline tax payments.
\end{abstract}

Keywords: book tax differences and earnings persistence.

\section{Pendahuluan}

Industri telekomunikasi memiliki peranan yang penting dalam kehidupan masyarakat maupun perekonomian nasional. Kontribusi pertumbuhan sektor jasa telekomunikasi merupakan sektor jasa dengan tingkat kontribusi yang cukup tinggi. Hal ini ditunjukkan oleh penerimaan pajak dan pertumbuhan pajak yang cukup stabil dari sektor komunikasi dalam kurun tiga tahun, yaitu tahun 2010 hingga tahun 2012 .

Laba yang tinggi menjadi harapan setiap perusahaan. Jika suatu perusahaan dapat menghasilkan laba yang tinggi, maka beberapa pihak pun akan memperoleh harapan atas beberapa hal, antara lain: 1) deviden yang tinggi bagi pemilik, 2) penentuan bonus yang akan diterima manajer, 3) kompensasi / insentif bagi para karyawan, 4) bagi kreditur laba yang tinggi dapat dijadikan sebagai alat untuk memprediksi besarnya penerimaan pokok atas pinjaman dan bunga yang diberikan, 5) bagi pemerintah semakin tinggi laba yang dihasilkan suatu perusahaan, maka 
semakin tinggi pula pajak penghasilan yang harus dibayarkan oleh perusahaan.

Laba yang berkualitas ialah laba yang dapat memberikan informasi bagi para pemakai laporan keuangan mengenai kelanjutan atas laba itu sendiri di masa yang akan datang. Sehingga informasi yang dihasilkan oleh laba yang berkualitas, dapat dijadikan alat pengambilan keputusan bagi pihak internal dan pihak eksternal. Informasi laba digunakan untuk mengevaluasi kinerja di masa lalu, sebagai dasar untuk memprediksi kinerja masa depan, dan membantu menilai resiko pencapaian arus kas masa depan.

Salah satu topik yang tengah berkembang di bidang akuntansi perpajakan yang menarik perhatian ialah mengenai book tax differences. Book tax differences adalah perbedaan antara besaran laba akuntansi (laba komersial) dengan besaran laba fiskal.

Berawal dari perbedaan pedoman dalam penyusunan laporan komersial dan laporan fiskal, maka timbul istilah laba komersial (laba akuntansi) dan laba fiskal. Perbedaan dasar penyusunan dalam penghitungan laba antara komersial dengan perpajakan maka menimbulkan perbedaan besaran jumlah atas penghasilan sebelum pajak (laba akuntansi) dan penghasilan kena pajak (laba fiskal) atau disebut dengan istilah book tax differences.

Perbedaan yang terjadi antara jumlah penghasilan sebelum pajak dengan penghasilan kena pajak disebabkan oleh perbedaan permanen (permanent differences) dan perbedaan temporer (temporary differences) atau disebut juga perbedaan waktu (timing differences). Perbedaan permanen merupakan perbedaan yang muncul akibat adanya perbedaan peraturan terkait pengakuan pendapatan dan biaya antara Standar Akuntansi Keuangan (SAK) dengan Ketentuan Peraturan
Perundang-undangan Perpajakan. Perbedaan temporer timbul sebagai akibat perbedaan waktu pengakuan atas pendapatan dan biaya menurut Standar Akuntansi Keuangan dengan Ketentuan Peraturan Perundang-undangan Perpajakan.

Rekonsiliasi fiskal menjadi solusi untuk menjembatani perbedaan permanen dan perbedaan temporer yang timbul akibat perbedaan tujuan dan dasar hukum antara laporan keuangan komersial dan laporan fiskal.

Terdapat sejumlah penelitian terdahulu yang telah meneliti kemungkinan perbedaan antara laba akuntansi dan laba fiskal (book tax differences) yang dapat menjadi sumber informasi yang berguna bagi para pemakai laporan keuangan. Beberapa peneliti di luar negeri membuktikan adanya indikasi praktik manajemen laba suatu perusahaan dapat dilihat dari book tax differences (Phillips et al., 2003; Tang, 2006; Ayers et al., 2008). Selain itu penelitian atas informasi yang dihasilkan oleh book tax differences dikaitkan dengan kualitas laba. Peneliti dari luar negeri dan dalam negeri mengemukakan bahwa laba fiskal (taxable income) dapat memberikan informasi mengenai kualitas laba (Manzon dan Plesko, 2002; Mills et al., 2002 dalam Lev dan Nissim et al., 2004; Michelle Hanlon 2005; Wiryandari dan Yulianti, 2008).

Hasil penelitian Yulianti (2005) menyimpulkan bahwa beban pajak tangguhan dan akrual signifikan secara statistik dalam mendeteksi manajemen laba. Hasil penelitian Djamaluddin, dkk. Menyimpulkan bahwa perusahaan dengan large positive (negative) booktax differences tidak terbukti secara statistik memiliki persistensi laba akuntansi yang lebih rendah dari perusahaan dengan small book-tax differences. Sedangkan hasil penelitian 
Wiryandri dan Yulianti (2009) menyimpulkan bahwa perusahaan dengan large book-tax differences akan memiliki laba satu periode ke depan yang kurang persisten dibanding perusahaan dengan small book-tax differences. Selain itu, disimpulkan bahwa beban pajak tangguhan dan akrual tidak signifikan dalam mendeteksi manajemen laba.

Berdasarkan penelitian-penelitian terdahulu dapat disimpulkan bahwa book tax differences berkaitan dengan informasi laba sehingga dapat digunakan untuk mengukur kinerja perusahaan. Book tax differences dapat dijadikan alat evaluasi laba akuntansi perusahaan. Hal ini didasari oleh alasan bahwa sedikit kebebasan yang diperbolehkan dalam menghitung laba fiskal, sehingga perbedaan laba akuntansi dan laba fiskal dapat mencerminkan informasi mengenai sejauh mana kebijakan manajemen dalam proses akrual.

Tujuan yang hendak dicapai dari penelitian adalah sebagai berikut: 1) Mengetahui gambaran umum dan karakteristik variabel perbedaan permanen dan variabel perbedaan temporer yang merupakan proksi dari book tax differences; 2) Mengetahui kelayakan model regresi yang digunakan dalam memprediksi hubungan antara variabel perbedaan permanen dan variabel perbedaan temporer terhadap persistensi laba, akrual dan aliran kas, sehingga dapat melihat pengaruh book tax differences terhadap perencanaan pajak suatu perusahaan; dan 3) Memperoleh bukti empiris mengenai pengaruh book tax differences terhadap persistensi laba, akrual, aliran kas dan perencanaan perpajakan.

\section{Metodologi Penelitian}

Penelitian ini menggunakan metode analisis regresi. Metode analisis regresi digunakan untuk mengetahui suatu pengaruh suatu variabel terhadap variabel lain. Beberapa asumsi yang harus dipenuhi dalam metode analisis regresi pada penelitian ini, yaitu 1) Uji Statistik Deskriptif, dan 2) Uji Asumsi Klasik.

\section{Hasil dan Pembahasan}

Pada hasil Uji F, diperoleh bukti empiris bahwa bahwa nilai $\mathrm{F}=8.946$ dengan probabilitas signifikan 0,000 . Karena signifikansi lebih kecil dari 0,05 maka dapat disimpulkan bahwa secara signifikan variabel Perbedaan Permanen, Perbedaan Temporer, Arus Kas Operasi dan Akrual secara bersama-sama berpengaruh terhadap Persistensi Laba. Variasi Persistensi Laba yang dapat dijelaskan oleh Perbedaan Permanen, Perbedaan Temporer, Arus Kas Operasi dan Akrual sebesar 40,3\%. Sedangkan sisanya sebesar 59,7\% Persistensi Laba dijelaskan oleh variabel lainnya yang tidak dimasukkan dalam model regresi. Berikut ini adalah pembahasan hipotesis hasil analisis uji statistik.

\section{Pengaruh Book Tax Difference terhadap Persistensi Laba \\ Pada hasil dari Uji t,} diperoleh bukti empiris bahwa book tax differences yang dijabarkan oleh perbedaan permanen dan perbedaan temporer memiliki nilai signifikansi masingmasing sebesar 0,013 dan 0,093. Nilai signifikansi kedua variabel tersebut lebih besar dari $\alpha=0,05$. Maka dapat ditarik kesimpulan bahwa variabel book tax differences yang diproksikan oleh perbedaan permanen dan perbedaan temporer tidak berpengaruh secara signifikan terhadap persistensi laba. Sehingga hipotesis yang menyatakan perbedaan permanen dan 
perbedaan temporer memiliki pengaruh terhadap persistensi laba, ditolak. Hasil penelitian ini mendukung temuan dari Budi Lestari (2011) yang menyatakan bahwa jumlah perbedaan permanen dan perbedaan temporer tidak signifikan dalam mempengaruhi jumlah laba kena pajak yang merupakan dasar perhitungan untuk beban pajak kini. Hal ini dimungkinkan karena penghasilan dan biaya yang memperoleh penyesuaian dalam rekonsiliasi fiskal, tidak berpengaruh terhadap revisi laba di masa depan. Revisi laba di masa depan dipengaruhi oleh manajemen laba yang dilakukan perusahaan untuk memenuhi harapan para investor.

\section{Pengaruh Variabel Kontrol terhadap Persistensi Laba}

Berdasarkan hasil uji $t$ menunjukkan bukti empiris bahwa variabel kontrol dalam penelitian ini, yaitu arus kas operasi dan akrual memiliki nilai signifikansi sebesar 0,027 dan 0,038. Masingmasing nilai signifikansi tersebut melebihi nilai $\alpha$, yaitu 0,05 . Maka dapat disimpulkan bahwa variabel kontrol yaitu arus kas operasi dan akrual tidak berpengaruh secara signifikan terhadap persistensi laba. Temuan ini mendukung hasil temuan Subekti Djamaludin dkk (2008) dan Iqbal Bayu Septiansyah (2010) yang menyatakan akrual secara statistik tidak terbukti dapat berpengaruh secara signifikan terhadap persistensi laba. Akrual juga tidak berpengaruh secara signifikan terhadap probabilitas perusahaan dalam melakukan manajemen laba. Hal tersebut dimungkinkan karena komponen akrual dan aliran kas dari aktivitas operasi cenderung kurang terulang pada periode yang akan datang, sehingga tidak berpengaruh positif terhadap persitensi laba.

\section{Pengaruh Book Tax Difference terhadap Perencanaan Pajak}

Perbedaan antara laba komersial dengan laba akuntansi (book tax differences) dapat menjadi indikasi manajemen perencanaan pajak. Hal tersebut dapat dilihat dari besarnya large positive book tax differences dan small book tax differences. Pada hasil uji statistik deskriptif, menunjukkan large positive book tax differences. Hal tersebut dapat dilihat dari besarnya nilai maksimum yang terdapat pada perbedaan temporer sebesar 79,3. Begitu pula pada nilai minimum yang kecil terdapat pada perbedaan temporer, sebesar $-9,6$. Berdasarkan nilai maksimum dan nilai minimum tersebut, dapat ditarik kesimpulan bahwa telah terjadi koreksi fiskal negatif lebih banyak dibanding koreksi fiskal positif. Sehingga terdapat penyesuaian terhadap penghasilan netto komersial. Koreksi fiskal negatif (large book tax differences) yang lebih besar dibanding koreksi fiskal positif, menunjukkan berkurangnya laba kena pajak pada perusahaan di satu periode laporan keuangan. Sehingga dapat ditarik kesimpulan bahwa tax planning yang diterapkan perusahaan telah efektif.

Perencanaan pajak yang dilakukan perusahaan merupakan tindakan tax avoidance. Bentuk dari tax avoidance tersebut diterapkan dalam pengakuan pendapatan dan pengakuan 
kerugian/beban yang ditangguhkan pada tahun yang akan datang. Sehingga dapat mengurangi besarnya beban pajak yang harus dibayar perusahaan. Hal ini mendukung temuan Soddin Mangunsong (2002) yang menyatakan perbedaan komersial dan laba kena pajak yang signifikan berperan dalam mengefisiensikan pembayaran pajak.

\section{Kesimpulan}

1. Book tax differences yang dijabarkan oleh perbedaan permanen dan perbedaan temporer tidak berpengaruh secara signifikan terhadap persistensi laba. Hal ini dimungkinkan karena penghasilan dan biaya yang memperoleh penyesuaian dalam rekonsiliasi fiskal, tidak berpengaruh terhadap revisi laba di masa depan. Revisi laba di masa depan dipengaruhi oleh manajemen laba yang dilakukan perusahaan untuk memenuhi harapan para investor. Hasil ini mendasari simpulan bahwa hipotesis yang menyatakan perbedaan permanen dan perbedaan temporer memiliki pengaruh terhadap persistensi laba, ditolak. Hasil penelitian ini mendukung temuan dari Budi Lestari (2011).

2. Variabel kontrol penelitian ini yaitu arus kas operasi dan akrual tidak berpengaruh secara signifikan terhadap persistensi laba. Hal tersebut dimungkinkan karena komponen akrual dan aliran kas dari aktivitas operasi cenderung kurang terulang pada periode yang akan datang, sehingga tidak berpengaruh positif terhadap persitensi laba. Temuan ini mendukung hasil temuan Subekti Djamaludin dkk (2008) dan Iqbal Bayu Septiansyah (2010).

3. Perbedaan antara laba komersial dengan laba akuntansi (book tax differences) dapat menjadi indikasi manajemen perencanaan pajak. Hal tersebut dapat dilihat dari besarnya large positive book tax differences. Koreksi fiskal negatif (large book tax differences) yang lebih besar dibanding koreksi fiskal positif, menunjukkan berkurangnya laba kena pajak pada perusahaan di satu periode laporan keuangan. Sehingga dapat ditarik kesimpulan bahwa tax planning yang diterapkan perusahaan telah efektif. Perencanaan pajak dapat mengurangi besarnya beban pajak yang harus dibayar perusahaan. Hal ini mendukung temuan Soddin Mangunsong (2002).

\section{Daftar Pustaka}

Anggraini, Fivi dan Ira Trisnawati. 2008. Pengaruh Eranings Management Terhadap Konservatisma Akuntansi. Jurnal Bisnis Dan Akuntansi. Vol. 1 (10): hal 23-36.

Bandi. 2009. Kualitas Laba Dalam Perspektif Akrual-Arus Kas Dan Pensinyalan Dividen. Disertasi. Semarang: Universitas Diponegoro.

Bayu Septiansyah, Iqbal. 2010. Pengaruh Book Tax Differences Terhadap Persistensi Laba Dan Manajemen Laba. Skripsi. Jakarta: Universitas Pembangunan Nasiona "Veteran".

Djamaluddin, Subekti. 2008. Analisis Perbedaan Antara Laba Akuntansi dan Laba Fiskal Terhadap Persistensi Laba, Akrual, dan aliran Kas pada Perusahaan Perbankan yang Terdaftar di Bursa Efek Jakarta. Jurnal Riset 
Akuntansi Indonesia. Vol. 11 (1): hal 52-74.

Djoko Muljono dan Baruni Wicaksono. 2009. Akuntansi Pajak Lanjutan. Yogyakarta: ANDI.

Epstein and Jermakowicz. 2008. International Financial Reporting Standards. Thompson. South Western.

Ghozali Imam. 2006. Aplikasi Analisis Multivariate dengan Program SPSS. Semarang: Badan Penerbit Universitas Diponegoro.

Gunadi. 2009. Akuntansi Pajak Edisi Revisi 2009. Jakarta: Grasindo.

Harahap, Sofyan Syahri.2007. Teori Akuntansi. Jakarta: Raja Grafindo Persada.

Leonardo, Antonius. 2007. Laba Kena Pajak Sebagai Analisis Untuk Mengukur Kualitas Laba Perusahaan Studi Kasus Pada PT. Great River International Tbk. Tesis. Depok: Universitas Indonesia.

Lestari, Budi. 2011. Analisis Pengaruh Bokk Tax Differences Terhadap Pertumbuhan Laba. Skripsi. Semarang: Universitas Diponegoro.

Mangoting, Yenni. 1999. Tax Planning: Sebuah Pengantar Sebagai Alternatif Meminimalkan Pajak. Jurnal Akuntansi Dan Keuangan. Vol. 1 (1): hal 43-53.

Mangunsong, Soddin. Peranan Tax Planning Dalam Mengefisiensikan Pembayaran Pajak Penghasilan. 2002. Jurnal Ilmiah Akuntansi. Vol. 2 (1): hal 44-54

Mattoasi. 2007. Persamaan dan Perbedaan Akuntansi Keuangan dengan Akuntansi Perpajakan. Jurnal INOVASI Fakultas Ilmu Sosial Universitas Negeri Gorontalo. Vol 4 (3): hal 28-40.

Suandy, Erly. 2008. Perencanaan Pajak Edisi 4. Jakarta: Salemba Empat.
Tri Wijayanti, Handayani. 2006. Analisis Pengaruh Perbedaan Antara Laba Akuntansi Dan Laba Fiskal Terhadap Persistensi Laba, Akrual, Dan Arus Kas.

Undang-Undang Republik Indonesia Nomor 36 Tahun 2008 Tentang Pajak Penghasilan. 